\title{
Article \\ Occurrence of KPC-Producing Escherichia coli in Psittaciformes Rescued from Trafficking in Paraíba, Brazil
}

\author{
Gedean Galdino da Cruz Silva ${ }^{1}$, Eloiza Helena Campana ${ }^{2}$, Priscylla Carvalho Vasconcelos ${ }^{1}$ (D), \\ Núbia Michelle Vieira da Silva ${ }^{1}$, Lauro Santos Filho ${ }^{2}$, Elma Lima Leite ${ }^{1}{ }^{\mathbb{D}}$, Patrícia Emília Naves Givisiez ${ }^{1}$, \\ Wondwossen Abebe Gebreyes ${ }^{3}$ and Celso José Bruno de Oliveira ${ }^{1,3, * \mathbb{C}}$
}

1 Laboratório de Avaliação de Produtos de Origem Animal (LAPOA), Departamento de Zootecnia, Centro de Ciências Agrárias, Universidade Federal da Paraíba, Areia-PB 58397-000, Brazil; gedean_gcs@hotmail.com (G.G.d.C.S.); pczootecnista.1@gmail.com (P.C.V.); nubia274@gmail.com (N.M.V.d.S.); limaleiteelma@gmail.com (E.L.L.); patricia@cca.ufpb.br (P.E.N.G.)

2 Laboratório de Microbiologia Clínica (LMC), Departamento de Ciências Farmacêuticas, Centro de Ciências da Saúde, Universidade Federal da Paraíba, João Pessoa-PB 58033-455, Brazil; elocampana@ccs.ufpb.br (E.H.C.); lauro.ufpb@hotmail.com (L.S.F.)

3 Global One Health Initiative (GOHi), Ohio State University, Columbus, OH 43210, USA; gebreyes.1@osu.edu

* Correspondence: celso.bruno.oliveira@gmail.com; Tel.: +55-83-98195-1075

check for

updates

Citation: Silva, G.G.d.C.; Campana, E.H.; Vasconcelos, P.C.; Silva, N.M.V.d.; Santos Filho, L.; Leite, E.L.; Givisiez, P.E.N.; Gebreyes, W.A.; Oliveira, C.J.B.d Occurrence of KPC-Producing Escherichia coli in Psittaciformes Rescued from Trafficking in Paraíba, Brazil. Int. J. Environ. Res. Public Health 2021, 18, 95. https://dx.doi.org/10.3390/ ijerph18010095

Received: 28 October 2020

Accepted: 11 November 2020

Published: 25 December 2020

Publisher's Note: MDPI stays neutral with regard to jurisdictional claims in published maps and institutional affiliations.

Copyright: (c) 2020 by the authors. Licensee MDPI, Basel, Switzerland. This article is an open access article distributed under the terms and conditions of the Creative Commons Attribution (CC BY) license (https: / / creativecommons.org/ licenses/by/4.0/).
Abstract: The emergence and spread of antimicrobial resistance pose a threat to public health globally. Antibiotic-resistant bacteria and genes can disseminate among environments, animals and humans. Therefore, investigation into potential reservoirs of multidrug-resistant bacteria is of great importance to the understanding of putative transmission routes of resistant bacteria and resistance genes. This study aimed to report the occurrence of Escherichia coli harboring the Klebsiella pneumoniae carbapenemase-producing gene $\left(b l a_{\mathrm{KPC}}\right)$ in Psittaciformes rescued from wildlife trafficking in Paraíba State, Brazil. Cloacal swabs were collected from thirty birds and cultured by conventional microbiology using MacConkey and serum tryptone glucose glycerol (STGG) media supplemented with selective antimicrobials. E. coli isolates $(n=43)$ were identified by phenotypic tests and confirmed by MALDI-TOF. Antimicrobial susceptibility profiles were determined by means of Kirby-Bauer test. All isolates were further screened for extended-spectrum beta-lactamase (ESBL) production, and putative genes encoding ESBL were investigated by PCR. Additionally, bla $a_{\mathrm{KPC}}$-harboring strains were genotyped by REP-PCR. A total of 43 E. coli phenotypically resistant isolates were recovered. The highest resistance rate was observed against ciprofloxacin. Among the resistance genes, only $b l a_{\mathrm{KPC}}$ was found in seven different birds from three species. According to the genotyping, these seven isolates belonged to four different strains. To date, this is the first report on the occurrence of KPC-E. coli in Psittaciformes rescued from trafficking in Northeastern Brazil. Due to the high clinical importance of KPC-E. coli, our findings suggest that wild animals in captivity at wildlife rescue centers can play a role as reservoirs of bacteria that are resistance to Critically Important antimicrobials in human medicine.

Keywords: antimicrobials; resistance genes; wildlife

\section{Introduction}

Antimicrobial resistance is a major threat to global public health. Despite being a natural phenomenon, the emergence and rapid dissemination of resistant bacteria are directly related to the inadequate use of antimicrobials, the unavailability of new drugs, the incorrect disposal of drugs and the inadequate treatment of effluents, generating serious clinical and economic consequences associated with increased morbidity and mortality of patients [1]. Therefore, antimicrobial resistance must be understood as a One Health issue involving epidemiological aspects related to humans, animals and the environment [2]. 
Although a large number of studies on antimicrobial resistance have been conducted and reported, most of them relate to humans and companion animal species. There is a lack of information on the potential role of wildlife in the epidemiology of antimicrobial resistance. Theoretically, wild birds could play a relevant role, as they inhabit many ecological niches and act as biomarkers, being able to acquire and disseminate antimicrobialresistant microorganisms from human, livestock, or environmental sources. Antimicrobialresistant $E$. coli have been identified among various European wild bird species, potentially serving as reservoirs of antimicrobial resistance genes [3]. There is evidence that some wild bird species can acquire antimicrobial-resistant strains directly from individuals during migration or through exposure to residues [4], even though antimicrobial resistance in wildlife seems to be more complex than simple anthropogenic causes [5].

The potential problems associated with antimicrobial resistance in wildlife are still poorly comprehended. In conservation captivity for instance, drug screening may be compromised and the reintroduction of rehabilitated species may be disrupted, as these animals could be reservoirs of multiresistant microorganisms to other free-living, domestic breeding species and humans [6]. The increasing interest in birds as pets is also a concern. Psittaciformes are one of the most common pets due to their easy adaptation, plumage colors and ability to imitate human sounds [7]. Bacterial resistance to critically important antimicrobials, such as carbapemens, which is normally associated with additional resistance against drugs of other classes [8], poses a risk to individuals in close contact with those birds.

The aim of this study was to report Klebsiella pneumoniae carbapenemase-producing Escherichia coli (KPC E. coli) in Psittaciformes rescued from wildlife trafficking in Paraíba State, Brazil.

\section{Materials and Methods}

\subsection{Study Design and Sampling}

The study was performed at the Center for Rescued Wild Animals of Paraíba State (Centro de Triagem de Animais Silvestres da Paraíba (CETAS-PB)), located in the Restinga de Cabedelo National Forest $\left(7^{\circ} 03^{\prime} 46.9^{\prime \prime} \mathrm{S}, 34^{\circ} 51^{\prime} 22.0^{\prime \prime} \mathrm{O}\right)$, under the approval of the Biodiversity Authorization and Information System no. 65316-1. Animal handling and sampling procedures were previously approved by the Ethics Committee on Animal Use of the Federal University of Paraíba (CEUA N 9504051018).

Duplicate cloacal swabs were collected from thirty newly rescued or rehabilitated Psittaciformes birds (Table 1). The species were captured from their enclosures with the aid of a polypropylene mesh and manually contained for later identification, clinical evaluation and collection of biological samples. Two sterile urethral swabs were used to sample the cloacal microbiota and individually placed into $4 \mathrm{~mL}$ of MacConkey broth (Kasvi, Brazil) and serum tryptone glucose glycerol (STGG) broth. The latter was prepared in-house using skim milk, tryptone, glucose and glycerin, as previously described [9]. The samples were stored in a thermal box and transported to the Clinical Microbiology Laboratory of the Federal University of Paraíba. 
Table 1. Psittaciformes species sampled for cloacal swabs at the Centro de Triagem de Animais Silvestres da Paraíba (CETAS-PB), located in the Restinga de Cabedelo National Forest, Paraíba State, Brazil.

\begin{tabular}{ccc}
\hline Species & Popular Name & Number of Individuals \\
\hline Amazona aestiva & Turquoise-fronted parrot & 10 \\
Amazona amazonica & Orange-winged parrot & 2 \\
Amazona festiva & Festive parrot & 1 \\
Ara ararauna & Blue-and-yellow macaw & 3 \\
Ara chloropterus & Red-and-green macaw & 3 \\
Ara macaw & Scarlet macaw & 1 \\
Diopsittaca nobilis & Red-shouldered macaw & 5 \\
Eupsittula aurea & Peach-fronted parakeet & 1 \\
Eupsittula cactorum & Cactus parakeet & 1 \\
Forpus xanthopterygius & Blue-winged parrotlet & 1 \\
Psittacara leucophthalmus & White-eyed parakeet & 1 \\
Thectocercus acuticaudatus & Blue-crowned parakeet & 1 \\
& & Total: 30 \\
\hline
\end{tabular}

\subsection{Microbial Isolation}

STGG samples were processed within two hours of sampling, and MacConkey broth samples were incubated at $37^{\circ} \mathrm{C}$ for $24 \mathrm{~h}$. For both media, $100 \mu \mathrm{L}$-aliquots were transferred to three MacConkey agar plates (BD, Franklin Lakes, NJ, USA), each supplemented with the following selective antimicrobials: (I) ceftriaxone $8 \mu \mathrm{g} / \mathrm{mL}$; (II) imipenem $1 \mu \mathrm{g} / \mathrm{mL}$; and (III) polymyxin B $3.5 \mu \mathrm{g} / \mathrm{mL}$. Plates were incubated aerobically at $35 \pm 2{ }^{\circ} \mathrm{C}$ for $18-24 \mathrm{~h}$. The morphological characteristics of the colonies were reported, and representative colonies were later transferred to tryptic soy agar (TSA) medium (BD), also supplemented with the same antimicrobial used in the original MacConkey plate. All recovered strains were stored at $-80^{\circ} \mathrm{C}$ in sterile cryopreservation tubes containing skim milk solution, distilled water and $15 \%$ glycerin.

\subsection{Bacterial Identification}

The isolates were phenotypically identified by biochemical tests in solid (Simmons Citrate, Triple Sugar Iron agar-TSI, Lysine Iron Agar-LIA, Urea and Phenylalanine) and semisolid media (Motidade, Indol and Ornithina-MIO).

Confirmation of bacterial species was performed by means of mass spectrometryflight time (MALDI-TOF MS) using the Bruker BioTyper (Bruker Corporation, Billerica, MA, USA). Briefly, the isolates on TSA agar were inoculated in triplicate directly into a 96-spot steel microplate (Bruker Daltonics). After air drying, $1 \mu \mathrm{L}$ of matrix solution ( $\alpha$-cyano-4-hydroxycinnamic acid) was placed over each inoculum. Raw spectra were processed and compared to a reference database using MALDI BioTyper software version 3.1 (Bruker Daltonics). The following standard Bruker interpretative criteria were used: unreliable identification (score 0.000-1.699); probable genus identification (score 1.700-1.999); secure genus and probable species identification (score 2.000-2.299); highly probable species identification (score 2.300-3.000). Therefore, reliable species identification was considered when a minimum 2.3 score was obtained in at least two wells for a given isolate.

\subsection{Antimicrobial Susceptibility Testing and ESBL Screening}

Antimicrobial susceptibility testing was performed by disk diffusion [10] for sulfamethoxazole + trimethoprim (25MCG); ertapenem (10MCG); meropenem (10MCG); imipenem (10MCG); amikacin (30MCG); ciprofloxacin (5MCG); tetracycline (30MCG); chloramphenicol (30MCG); ceftriaxone (30MCG); ceftazidime (30MCG); ampicillin + sulbactam (20MCG); aztreonam (30MCG) and amoxicillin/clavulanic-acid (30MCG). E. coli ATCC 25,922 and Pseudomonas aeruginosa ATCC 27,853 were used as quality controls, and 
results were interpreted according to the Clinical Laboratory Standard Institute [11]. ESBL detection was carried out by double-disk synergy test (DDS), as previously described [12].

\subsection{Detection of Genes Encoding for Resistance by PCR and Genetic Relatedness Analysis by REP-PCR}

Genomic DNA was extracted by the modified phenol-chloroform-isoamyl alcohol method [13] and used as a template in the PCR assays targeting the genes bla $a_{\mathrm{CTX}}, b a_{\mathrm{NDM}}$, $b l a_{\mathrm{KPC}}$ and $m c r-1$. The primers and cycling conditions are shown in Table 2. KPC-positive E. coli isolates were genotyped by Repetitive Extragenic Palindromic Sequences PCR (REPPCR), as previously described [14].

Table 2. Oligonucleotide primers and thermal cycling conditions used in the PCR assays targeting genes conferring resistance against beta-lactamase (CTX-M), carbapenems (NDM and KPC) and colistin (MCR-1).

\begin{tabular}{|c|c|c|c|c|}
\hline \multicolumn{5}{|c|}{ Genes Encoding for Beta-Lactamase Resistance } \\
\hline Gene & Sequences $\left(5-3^{\prime}\right)$ & Amplicon size $\left(B P^{1}\right)$ & $T C^{2}$ & Reference \\
\hline blaCTX-M F & SCSATGTGCAGYACCAGTAA & 554 & & [15] \\
\hline blaCTX-M R & CCGCRATATGRTTGGTGGTG & & & \\
\hline \multicolumn{5}{|c|}{ Genes Encoding for Carbapenems Resistance } \\
\hline Gene & Sequences $\left(5-3^{\prime}\right)$ & Amplicon $\left(B P^{1}\right)$ & $T C^{2}$ & Reference \\
\hline blaNDM F & GGTTTGGCGATCTGGTTTTC & 621 & 2 & [16] \\
\hline blaNDM R & CGGAATGGCTCATCACGATC & & & \\
\hline blaKPC-2 F & TCGCCGTCTAGTTCTGCTGTCTTC & 800 & 3 & [17] \\
\hline blaKPC-3 R & CAATCCCTCGAGCGCGAGTC & & & \\
\hline \multicolumn{5}{|c|}{ Genes Encoding for Colistin Resistance } \\
\hline Gene & Sequences $\left(5-3^{\prime}\right)$ & Amplicon $\left(B P^{1}\right)$ & $T C^{2}$ & References \\
\hline MCR-1 F & GATCGGATTGGAGAACCAGA & 343 & 4 & [15] \\
\hline MCR-1 R & ATTTCTGACCGCATTTCCAT & & & \\
\hline \multicolumn{5}{|c|}{ 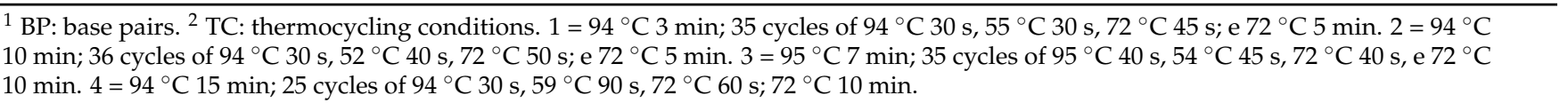 } \\
\hline \multicolumn{5}{|c|}{ 3. Results } \\
\hline \multicolumn{5}{|c|}{$\begin{array}{l}\text { Out of the thirty sampled birds, } 19(63.3 \%) \text { showed bacterial growth in at least one } \\
\text { of the three antimicrobial-supplemented agar dishes. A higher recovery was observed in } \\
\text { MacConkey broth }(28 / 90 ; 31.1 \%) \text { in comparison with STGG }(13 / 90 ; 14.4 \%) \text {. This difference } \\
\text { might be associated with the longer incubation period }(24-48 \mathrm{~h}) \text { for samples in MacConkey } \\
\text { broth. Considering the three types of antimicrobial supplementation, a higher frequency } \\
\text { was observed in the plates containing polymyxin B (Table } 3) \text {. }\end{array}$} \\
\hline
\end{tabular}

Table 3. Positive cloacal swabs and number of E. coli-confirmed samples from Psittaciformes under captivity at the Centro de Triagem de Animais Silvestres da Paraíba (CETAS-PB), located in the Restinga de Cabedelo National Forest, Brazil.

\begin{tabular}{|c|c|c|c|c|c|c|}
\hline \multirow{2}{*}{ Broth } & \multirow{2}{*}{ Growth } & \multicolumn{3}{|c|}{ Antimicrobial Supplementation } & \multirow{2}{*}{ Number of Isolates } & \multirow{2}{*}{$\begin{array}{l}\text { Confirmed } E \text {. coli } \\
\text {-Positive Isolates }\end{array}$} \\
\hline & & Cef ${ }^{1}$ & $I m i^{2}$ & Poly $B^{3}$ & & \\
\hline MacConkey & $28 / 90$ & $05 / 28$ & $7 / 28$ & $16 / 28$ & $36 / 71$ & $25 / 71$ \\
\hline STGG $^{4}$ & $13 / 90$ & $03 / 13$ & $0 / 13$ & $10 / 13$ & $24 / 71$ & $19 / 71$ \\
\hline
\end{tabular}

${ }^{1}$ Cef: ceftriaxone; ${ }^{2}$ Imi; imipenem; ${ }^{3}$ Poly B: polymyxin B; ${ }^{4}$ STGG: skim milk, tryptone, glucose and glycerin.

The antimicrobial susceptibility profiles of the E. coli isolates are shown in Table 4 . The highest resistance rates were observed for ciprofloxacin $(11.7 \%)$, ertapenem $(9.3 \%)$ and ceftazidime $(9.3 \%)$. The majority of the isolates were susceptible to different classes of antimicrobials, such as aztreonam (95.2\%), sulfamethoxazole + trimethoprim $(93.0 \%)$, imipenem $(93.0 \%)$, amikacin $(93.0 \%)$, tetracycline $(93.0 \%)$, chloramphenicol $(93.0 \%)$ and ceftriaxone (93.0\%). In addition, no ESBL phenotype was detected among the investigated isolates. 
Table 4. Susceptibility profiles of cloacal E. coli isolated from trafficked Psittaciformes under captivity at the Centro de Triagem de Animais Silvestres da Paraíba (CETAS-PB), located in the Restinga de Cabedelo National Forest, Brazil.

\begin{tabular}{|c|c|c|c|c|c|c|c|}
\hline \multirow{2}{*}{ Antimicrobials } & \multirow{2}{*}{ Initials } & \multicolumn{6}{|c|}{ Susceptibility Profile } \\
\hline & & $S^{1}$ & $\%$ & $\mathrm{I}^{2}$ & $\%$ & $\mathbf{R}^{3}$ & $\%$ \\
\hline Sulfamethoxazole + trimethoprim ${ }_{(25 \mathrm{MCG})}$ & SUT & 40 & 93.0 & 1 & 2.4 & 2 & 4.6 \\
\hline Ertapenem $(10 \mathrm{MCG})$ & ETP & 36 & 83.7 & 3 & 7.0 & 4 & 9.3 \\
\hline Meropenem (10MCG) & $M E R$ & 38 & 88.4 & 3 & 7.0 & 2 & 4.6 \\
\hline Imipenem (10MCG) & $I P M$ & 40 & 93.0 & 3 & 7.0 & 0 & 0.0 \\
\hline Amikacin (30MCG) & $A M I$ & 40 & 93.0 & 3 & 7.0 & 0 & 0.0 \\
\hline Ciprofloxacin (5MCG) & CIP & 31 & 72.0 & 7 & 16.3 & 5 & 11.7 \\
\hline Tetracycline (30MCG) & TET & 40 & 93.0 & 1 & 2.4 & 2 & 4.6 \\
\hline Chloramphenicol (30MCG) & CLO & 40 & 93.0 & 1 & 2.4 & 2 & 4.6 \\
\hline Ceftriaxone $(30 \mathrm{MCG})$ & $\mathrm{CRO}$ & 40 & 93.0 & 2 & 4.6 & 1 & 2.4 \\
\hline Ceftazidime (30MCG) & $C A Z$ & 37 & 86.1 & 2 & 4.6 & 4 & 9.3 \\
\hline Ampicillin + sulbactam (20MCG) & APS & 38 & 88.4 & 2 & 4.6 & 3 & 7.0 \\
\hline Aztreonam (30MCG) & ATM & 41 & 95.2 & 1 & 2.4 & 1 & 2.4 \\
\hline Amoxicillin/acid-clavulanic (30MCG) & $A C M$ & 39 & 90.6 & 1 & 2.4 & 3 & 7.0 \\
\hline
\end{tabular}

${ }^{1}$ S: susceptible; ${ }^{2}$ I: intermediate; ${ }^{3}$ R: resistant.

Among the antimicrobial resistance genes targeted by PCR, $b l a_{\mathrm{KPC}}$ was the only resistance determinant detected in 13 isolates originated from seven distinct bird species: one orange-winged parrot (Amazona amazonica), one scarlet macaw (Ara macao), one red-andgreen macaw (Ara chloropterus), one blue-and-yellow macaw (Ara ararauna), two turquoisefronted parrots (Amazona aestiva) and one festive parrot (Amazona festiva) (Table 5).

Table 5. blaKPC-positive E. coli isolated from trafficked Psittaciformes kept at the Centro de Triagem de Animais Silvestres da Paraíba (CETAS-PB), located in the Restinga de Cabedelo National Forest, Brazil.

\begin{tabular}{|c|c|c|c|c|c|}
\hline Sample Number & Species & Animal Id ${ }^{1}$ & Enrichment Broth ${ }^{2}$ & ATB Supplementation ${ }^{3}$ & Genotype $^{4}$ \\
\hline 01 & Ara ararauna & ARA 2 & STGG & Poli B & II \\
\hline 02 & Ara ararauna & ARA 2 & STGG & Poli B & II \\
\hline 03 & Ara ararauna & ARA 2 & STGG & Poli B & II \\
\hline 04 & Ara macao & ARA 4 & STGG & Poli B & III \\
\hline 05 & Ara chloropterus & ARA 5 & STGG & Poli B & IV \\
\hline 06 & Ara chloropterus & ARA 5 & STGG & Poli B & II \\
\hline 07 & Ara chloropterus & ARA 5 & STGG & Poli B & II \\
\hline 08 & Amazona aestiva & PAP 8 & STGG & Poli B & I \\
\hline 09 & Amazona aestiva & PAP 8 & MAC & Imi & I \\
\hline 10 & Amazona festiva & PAP 9 & STGG & Poli B & I \\
\hline 11 & Amazona amazonica & PAP 11 & STGG & Poli B & I \\
\hline 12 & Amazona amazonica & PAP 11 & STGG & Poli B & I \\
\hline 13 & Amazona aestiva & PAP 12 & MAC & Imi & I \\
\hline
\end{tabular}

\footnotetext{
${ }^{1}$ Animal identification: ARA (Ara genus) or Amazona genus (PAP); ${ }^{2}$ Enrichment broth showing bacterial growth: STGG (skim milk, tryptone, glucose and glycerin) or MacConkey (MAC); ${ }^{3}$ Type of antibiotic supplementation in enrichment broth showing bacterial growth: polymyxin B (PoliB) or imipenem (IMI); ${ }^{4}$ Genotypic pattern by means of Rep-PCR.
}

The genotypic relatedness analysis by REP-PCR (Figure 1) indicated that the 13 blaKPCharboring E. coli clustered in four distinct genotypes (genotype I: samples 08, 09, 10, 11, 12 and 13 from three Amazona species; genotype II: samples 01, 02, 03, 06 and 07 from two Ara species; genotype III: sample 04 from Ara macao; and genotype IV: sample 05 from Ara chloropterus) (Figure 1). It is worth noting that two different KPC-E. coli strains (No. 05/genotype IV and No. 06/genotype II) were recovered from a single Ara chloropterus bird (ARA 5). Interestingly, genotype I predominated among E. coli recovered from Amazona birds, while genotypes II and IV were detected in the genus Ara only. 


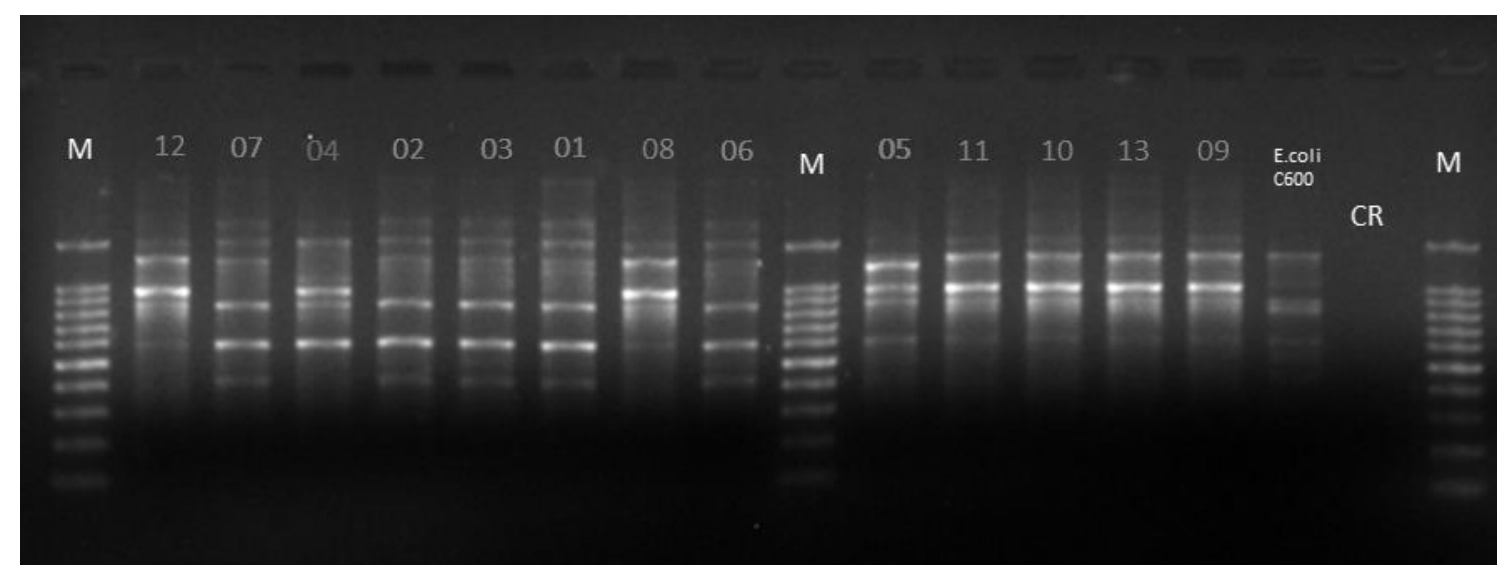

Figure 1. Genotypic relatedness of Klebsiella pneumoniae carbapenemase-producing - Escherichia coli (KPC E. coli) isolated from trafficked Psittaciformes under captivity at the Centro de Triagem de Animais Silvestres da Paraíba (CETAS-PB), located in the Restinga de Cabedelo National Forest, Brazil.Genotype I: samples 08, 09, 10, 11, 12 and 13; Genotype II: samples 01, 02, 03, 06 and 07; Genotype III: sample 04 and Genotype IV: sample 05.

Only strains 09 and 13 (genotype I) were recovered from MacConkey media supplemented with imipenem, whereas the majority of the blaKPC-E. coli were isolated from STGG media supplemented with polymyxin B.

\section{Discussion}

The detection of $b l a_{\mathrm{KPC}}$ in 13 different $E$. coli isolates harboring no bla could explain their observed phenotypic antimicrobial resistance patterns. However, these isolates have not been investigated for other extended-spectrum beta-lactamase genes that are commonly found in E. coli, such as bla $a_{\mathrm{TEM}}$ and bla $a_{\mathrm{SHV}}$. Although there was a higher isolation rate of antimicrobial-resistant bacteria in MacConkey compared with STGG broth, the majority of the blaKPC-E. coli were recovered from STGG media supplemented with polymyxin B. This interesting finding indicates that imipenem-resistant $E$. coli are probably more demanding in terms of bacteriological cultivation, and highlights the potential limitations of protocols targeting the detection of antimicrobial-resistant bacteria.

Human activities such as degradation and fragmentation of natural habitats force interaction among humans, wildlife and domestic animals, favoring the transmission of multiresistant bacteria among different species. E. coli are commensal bacteria abundantly present in the intestinal microbiota of animal species. In this context, the spread of antimicrobial resistance among abundant species such as E. coli poses a concern, since acquired resistance in these bacteria is frequently associated with mobile genetic elements, such as plasmids, transferred by horizontal mechanisms [5]. On the other hand, anthropogenic causes have not been clearly identified as major drivers determining antimicrobial resistance in wildlife [6].

Little is known about the true protocooperative role of $E$. coli in the enteric functioning of the hosts. It is known that, in wild birds, some pathogenic strains can lead to severe clinical conditions [18]. According to Sanches [19], birds are commonly infected with enteropathogenic Escherichia coli (EPEC) strains, a typical pathotype for these animals. Previous studies have reported greater intestinal colonization by EPEC in captive parrots compared to free-living birds [18]. Such findings can possibly be explained by factors related to feeding, hygiene of the enclosures and the use of antimicrobials. Under captivity, Psittaciformes may play an important role in maintaining cycles of antimicrobial-resistant enteric colibacillosis, with a potential impact on public health.

The transmission of resistant bacterial strains in wild species is directly linked to contact with effluents, elimination of solid residues, excreta of farm animals and propagation by synanthropic rodents [20]. Another important driver is migratory birds, which may carry bacteria harboring resistance determinants of emerging importance [15]. As reported 
by Dolejska and Literak [21], bla $a_{\mathrm{KPC}-2}$ and bla $a_{\mathrm{OXA}-48}$ genes were reported in E. coli from seagulls. Low but frequent detection of carbapenemase-producing E. coli in wild birds in Alaska may indicate environmental dissemination of these bacteria in sites with relatively low levels of food animal farming and without previous evidence of carriage by the human clinical population [22].

The $b l a_{\mathrm{KPC}}$ gene has already been reported among E. coli from different bird species belonging to the Columbiformes, Passeriformes, Charadriiformes, Accipitriformes, Falconiformes and Strigiformes orders [23]. In Brazil, Pontes et al. [24] detected the resistance genes str $\mathrm{AB}$, bla TEM, tet $\mathrm{A}$, tet $\mathrm{B}$, aad $\mathrm{A}$, apha $\mathrm{A}$, sul1, sul2, and sul 3 associated with plasmids in cloacal avian pathogenic Escherichia coli (APEC) strains from Nymphicus hollandicus in São Paulo and Rio de Janeiro. Cloacal E. coli from Pyrrhura griseipectus was phenotypically resistant to azithromycin, sulfamethoxazole-trimethoprim, streptomycin and tetracycline [25]. Resistance to tobramycin and streptomycin was observed in cloacal E. coli from Amazona aestiva, Ara chloroptera and Ara ararauna from Parque das Aves de Toledo, Paraná (Brazil) [7]. However, surveillance of antimicrobial-resistant bacterial strains in wildlife is usually performed by means of phenotypic testing.

Besides the high number of $E$. coli strains carrying $b l a_{\mathrm{KPC}}$, the fact that two unrelated KPC-E. coli strains were recovered from a single bird (ARA 5) suggests that this gene could be disseminated through mobile genetic elements such as plasmids.

The first carbapenemase-producing E. coli in wild birds was associated with Milvus migrans in Germany [26]. Our study is the first to report Psittaciformes as carriers of carbapenemase-producing E. coli in Brazil. Considering most studies in wildlife do not target molecular mechanisms of antimicrobial resistance and normally report phenotypic resistance patterns of bacteria, our results suggest that Psittaciforms are still underestimated as potential reservoirs of multiresistant Enterobacteriacea. Considering the increasing importance of Psittaciforms as pets and their high abundance in rescue centers, further studies are warranted to understand the role of these animals in the epidemiology of antimicrobial resistance and the public heath impact.

\section{Conclusions}

The occurrence of KPC-producing E. coli in the cloaca of Psittaciformes rescued from trafficking highlights the potential role of wildlife birds in the epidemiology of antimicrobial resistance. In view of the increasing importance of rescue and rehabilitation centers around the world, attention is needed in order to avoid hard-to-treat occupational infections in humans in close contact to the birds, and also mitigate the dissemination of antimicrobial resistance associated with the return of birds to native environments.

Author Contributions: Conceptualization, C.J.B.d.O., W.A.G., E.H.C.; methodology, N.M.V.d.S., G.G.d.C.S., E.L.L.; validation, N.M.V.d.S., P.C.V.; formal analysis, N.M.V.d.S., G.G.d.C.S., P.C.V.; investigation, G.G.d.C.S., P.C.V., N.M.V.d.S., E.L.L.; resources, L.S.F., E.H.C.; data curation, G.G.d.C.S., P.C.V; writing-original draft preparation, C.J.B.d.O., E.H.C., P.E.N.G., W.A.G.; writing-review and editing, C.J.B.d.O., G.G.d.C.S., E.L.L., E.H.C., L.S.F.; visualization, P.C.V., N.M.V.d.S., W.A.G; supervision, C.J.B.d.O., L.S.F., E.H.C.; project administration, E.H.C; funding acquisition, C.J.B.d.O., P.E.N.G. All authors have read and agreed to the published version of the manuscript.

Funding: This research was funded by the Coordenação de Aperfeiçoamento de Pessoal de Nível Superior-Brasil (CAPES)_Finance Code 001. Scholarships were provided by Conselho Nacional de Pesquisa e Desenvolvimento (CNPq) — proc. 311793/2016-9.

Acknowledgments: The authors are thankful to Centro de Triagem de Animais Silvestres da Paraíba (CETAS-PB). This study was conducted with financial support from CNPq and CAPES.

Conflicts of Interest: The authors declare that they have no conflict of interest. 


\section{References}

1. Sousa, A.T.H.I.; Makino, H.; Bruno, V.C.M.; Candido, S.L.; Nogueira, B.S.; Menezes, I.G.; Nakazato, L.; Dutra, V. Perfil de resistência antimicrobiana de Klebsiella pneumoniae isoladas de animais domésticos e silvestres. Arq. Bras. Med. Vet. Zootec. 2019, 71, 584-593. [CrossRef]

2. Rousham, E.K.; Unicomb, L.; Islam, M.A. Human, animal and environmental contributors to antibiotic resistance in low-resource settings: Integrating behavioural, epidemiological and One Health approaches. Proc. R. Soc. 2018, 285, 20180332. [CrossRef] [PubMed]

3. Silva, F.L.; Palácio, S.B.; Garcia, J.E.; Cavalcanti, I.M.F. Dissemination of multidrug-resistant bacteria in birds. Appro. Poult. Dairy Vet. Sci. 2018, 3, 257-259.

4. Guenther, S.; Grobbel, M.; Lübke-Becker, A.; Goedecke, A.; Friedrich, N.D.; Wieler, L.H.; Ewers, C. Antimicrobial resistance profiles of Escherichia coli from common European wild bird species. Vet. Microbiol. 2010, 144, 219-225. [CrossRef] [PubMed]

5. Arnold, K.E.; Williams, N.J.; Bennett, M. Disperse abroad in the land: The role of wildlife in the dissemination of antimicrobial resistance. Biol. Lett. 2016, 12, 20160137. [CrossRef]

6. Swift, B.M.C.; Bennett, M.; Waller, K.; Dodd, C.; Murray, A.; Gomes, R.L.; Humphreys, B.; Hobman, J.L.; Jones, M.A.; Whitlock, S.E.; et al. Anthropogenic environmental drivers of antimicrobial resistance in wildlife. Sci. Total Environ. 2019, 649, 12-20. [CrossRef]

7. Trindade, L.C.; Figueira, P.T. Perfil de susceptibilidade antibacteriana e produção de hemolisina de enterobactérias de psitacídeos em cativeiro. Pubvet 2018, 12, 1-5. [CrossRef]

8. Stoesser, N.; Sheppard, A.E.; Peirano, G.; Anson, L.W.; Pankhurs, T.L.; Sebra, R.; Phan, H.T.T.; Kasarskis, A.; Mathers, A.J.; Peto, T.E.A.; et al. Genomic epidemiology of global Klebsiella pneumoniae carbapenemase (KPC)—Producing Escherichia Coli. Sci. Rep. 2017, 7, 5917. [CrossRef]

9. Gibson, L.F.; Khoury, J.T. Storage and survival of bacteria by ultra-freeze. Lett. Appl. Microbiol. 1986, 3, 127-129. [CrossRef]

10. Clinical and Laboratory Standards Institute-CLSI. Methods for Dilution Antimicrobial Susceptibility Tests for Bacteria That Grow Aerobically. In CLSI Document M07-A9; CLSI: Wayne, PA, USA, 2012.

11. Clinical and Laboratory Standards Institute-CLSI. Performance Standards for Antimicrobial Susceptibility Testing. In CLSI Document M100-S27; CLSI: Wayne, PA, USA, 2017.

12. Jarlier, V.; Nicolas, M.-H.; Fournier, G.; Philippon, A. Extended broadspectrum beta-lactamases conferring transferable resistance to newer beta-lactam agents in Enterobacteriaceae: Hospital prevalence and susceptibility patterns. Rev. Infect. Dis. 1988, 10, 867-878. [CrossRef]

13. Sambrook, J.; Fritsch, E.F.; Maniatis, T. Molecular cloning. A Laboratory Manual, 2nd ed.; Cold Spring Harbor Laboratory Press: New York, NY, USA, 1989.

14. Van Der Zee, U.; Verbakel, H.; Van Zon, J.C.; Frenay, I.; Van Belkum, A.; Peeters, M.; Buiting, U.; Bergmans, U. Molecular genotyping of Staphylococcus aureus strains: Comparison of repetitive elemento sequence-based PCR with various typing methods and isolation of a novel epidemicity marker. J. Clin. Microbiol. 1999, 37, 342-351. [CrossRef] [PubMed]

15. Liu, Y.Y.; Wang, Y.; Walsh, T.R.; Yi, L.X.; Zhang, R.; Spencer, J.; Doi, Y.; Tian, G.; Dong, B.; Huang, X.; et al. Emergence of plasmid-mediated colistin resistance mechanism MCR-1 in animals and human beings in China: A microbiological and molecular biological study. Lancet. Infect. Dis. 2015, 16, 161-168. [CrossRef]

16. Poirel, L.; Schrenzel, J.; Cherkaoui, A.; Bernabeu, S.; Renzi, G.; Nordmann, P. Molecular analysis of NDM-1-producing enterobacterial isolates from Geneva, Switzerland. J. Antimicrob. Chemother. 2011, 66, 1730-1733. [CrossRef] [PubMed]

17. Hossain, A.; Ferraro, M.J.; Pino, R.M.; Dew, R.B.; Moland, E.S.; Lockhart, T.J.; Thomson, K.S.; Goering, R.V.; Hanson, N.D. Plasmid Mediated Carbapenem-Hydrolyzing Enzyme KPC-2 in an Enterobacter sp. Antimicrob. Agents. Chemother. 2004, 48, 4438-4440. [CrossRef] [PubMed]

18. Lopes, E.S.; Maciel, W.C.; Albuquerque, A.H.; Machado, D.N.; Bezerra, W.G.A.; Vasconcelos, R.H.; Lima, B.P.; Gonçalves, G.A.M.; Teixeira, R.S.C. Prevalence and antimicrobial resistance profile of Enterobacteria isolated from Psittaciformes of illegal wildlife trade. Acta. Sci. Vet. 2016, 43, 1313.

19. Sanches, L.A.; Gomes, M.S.; Texeira, R.H.F.; Cunha, M.P.V.; Oliveira, M.G.X.; Vieira, M.A.M.; Gomes, T.A.T.; Knobl, T. Captive wild birds as reservoirs of enteropathogenic E. coli (EPEC) and Shiga-toxin producing E. coli (STEC). Braz. J. Microbiol. 2017, 48, 760-763. [CrossRef]

20. Hassell, J.M.; Ward, M.J.; Muloi, D.; Bettridge, J.M.; Robison, T.P.; Kariuki, S.; Ogendo, A.; Kiiru, J.; Imboma, T.; Kang'ethe, E.K.; et al. Clinically relevant antimicrobial resistance at the wildlife-livestock-human interface in Nairobi: An epidemiological study. Lancet. Planet. Health 2019, 3, 259-269. [CrossRef]

21. Dolejska, M.; Literak, I. Wildlife is overlooked in the epidemiology of medically important antibiotic-resistant bacteria. Antimicrob. Agents. Chomother. 2019, 63, e01167-19. [CrossRef]

22. Ahlstrom, C.A.; Ramey, A.M.; Woksepp, H.; Bonnedahl, J. Repeated detection of carbapenemase-producing Escherichia coli in gulls inhabiting Alaska. Antimicrob. Agents Chemother. 2019, 63, e00758-19. [CrossRef]

23. Sigirci, B.D.; Celik, B.; Halac, B.; Adiguzel, M.C.; Kekec, I.; Metiner, K.; Ikiz, S.; Bagcigil, A.F.; Ozgur, N.Y.; Ak, S.; et al. Antimicrobial resistance profiles of Escherichia coli isolated from companion birds. J. King. Saud. Univ. Sci. 2020, 32, $1069-1073$. [CrossRef] 
24. Pontes, O.S.; Coutinho, D.A.S.; Iovine, R.O.; Cunha, M.P.V.; Knöbl, T.; Carvalho, V.M. Survey on pathogenic Escherichia coli and Salmonella spp. in captive cockatiels (Nymphicus hollandicus). Braz. J. Microbiol. 2019, 49, 76-82. [CrossRef] [PubMed]

25. Machado, D.N.; Lopes, E.S.; Albuquerque, Á.H.; Bezerra, W.G.A.; Horn, R.V.; Lima, S.V.G.; Siqueira, R.A.S.; Beleza, A.J.F.; Oliveira, F.R.; Cardoso, W.N.; et al. Deteç̧ão e avaliação do perfil de sensibilidade antibacteriana de enterobactérias isoladas de periquitos cara-suja (Pyrrhura griseipectus) em cativeiro. Arq. Bras. Med. Vet. Zootec. 2016, 68, 1732-1736. [CrossRef]

26. Wang, J.; Ma, Z.-B.; Zeng, Z.-L.; Yang, X.-W.; Huang, Y.; Liu, J.-H. The role of wildlife (wid birds) in the global transmission of antimicrobial resistance genes. Zool. Res. 2017, 38, 55-80. [CrossRef] [PubMed] 